УДК 159.96-316.6

DOI: https://doi.org/10.33120/popp-Vol24-Year2021-70

\author{
Василець Катерина Віталіївна \\ здобувач ступеня $\mathrm{PhD}$, \\ Інститут соціальної і політичної психології НАПН України, \\ м. Київ, Україна \\ ORCID ID 0000-0002-6670-089X \\ k.v.vasilets@gmail.com
}

\title{
ОСОБЛИВОСТІ МОРАЛЬНОЇ СВІДОМОСТІ В УМОВАХ НАДЗВИЧАЙНИХ СИТУАЦІЙ
}

Актуальність. Надзвичайні ситуації значною мірою впливають на психологічний стан населення. Останнім часом спостерігається зростання кількості надзвичайних ситуацій, що спонукає науковців різних галузей до удосконалення способів формування психологічної готовності населення та представників спеціалізованих служб. Моральна сторона сприйняття надзвичайних ситуацій $є$ малодослідженою, хоча, поза сумнівом, істотно впливає на оцінку ситуації та процес її опанування. Моральна свідомість формується під впливом життєвого досвіду і продукує в кожної людини власну систему цінностей та переконань. Незважаючи на те, що більшість моральних норм i принципів $\epsilon$ спільними для всього суспільства, кожна людина інтерпретує їх у зручний i зрозумілий для себе спосіб. Це пояснює той факт, що моральна свідомість кожної людини як регулятор поведінки проявляється по-різному. 3 цього погляду вивчення моральної свідомості в умовах надзвичайних ситуацій стає актуальним науковим завданням.

Метою статті є презентація висновків теоретичного аналізу наукового доробку 3 проблеми дослідження моральної свідомості та психологічної готовності особистості як взаємопов'язаних компонентів, що впливають на поведінку особистості в умовах надзвичайних ситуацій.

У результаті огляду наукових джерел встановлено, що моральна свідомість впливає на формування психологічної готовності та вибір стратегії поведінки в умовах надзвичайних ситуацій. Моральна свідомість як регулятор поведінки розглядається в межах теорії моральних основ, що $є$ новим напрямом досліджень у вітчизняній психологічній науці. Вибір напряму дослідження зазначеного феномену обгрунтовується тим, що теорія моральних основ розкриває природу моральної регуляції під новим кутом зору.

Перспективи практичного застосування результатів дослідження пов'язані з представленням і розкриттям нового підходу до розуміння моральної свідомості та ії компонентів. Ця проблематика потребує емпіричного дослідження відповідно до виокремлених компонентів моральної свідомості. Отримані результати можуть бути використані під час розроблення програм та методичних 
рекомендацій щодо розвитку психологічної готовності громадян і працівників спеціалізованих служб, а також у межах подальших досліджень у психології опанування.

Ключові слова: моральна свідомість; психологічна готовність; моральнопсихологічний стан; теорія моральних основ.

Kateryna V. Vasylets,

$\mathrm{PhD}$ candidate, Institute of Social and Political Psychology, NAES of Ukraine, Kyiv, Ukraine.

ORCID ID 0000-0002-6670-089X

k.v.vasilets@gmail.com

\section{PECULIARITIES OF MORAL CONSCIOUSNESS IN EMERGENCY SITUATIONS}

Relevance of the article. Emergencies have a significant impact on the psychological state of the population. In recent years, there has been an increase in emergencies, which prompts researchers from various areas to improve the ways of forming the psychological preparedness of the population and representatives of specialized services. The moral side of the emergencies' perception is poorly researched, although undoubtedly it has an important impact on assessing the situation and the process of its mastering. Moral consciousness is being formed under life experience impact and forms up each person's own system of values and beliefs. Although most moral norms and principles are common to all society, each person interprets them in a way that is convenient and understandable to him or her. This explains the fact that each person's moral consciousness as a behavior regulator manifests itself differently. From this point of view, the study of moral consciousness in emergencies is an urgent scientific task.

The article aims to present the theoretical analysis findings of scientific heritage on studying moral consciousness and psychological preparedness of personality as interrelated components influencing the behavior of the individual in emergencies.

The review of research reference material revealed that moral consciousness has an impact on the formation of psychological readiness and the choice of behavior strategy in emergencies. Moral consciousness as a behavior regulator is considered within the theory of moral foundations, which is a new research area in Ukrainian science. The choice of research of the mentioned phenomenon is justified by the fact that the theory of moral foundations reveals the nature of moral regulation from a new point of view.

Prospects for the practical application of the research results are associated with the presentation and disclosure of a new approach to the understanding of moral consciousness and its components. This problem requires empirical research in accordance with the highlighted components of moral consciousness. The results obtained can be used to elaborate methodological recommendations and programs for the development of psychological readiness of citizens and employees of specialized services, as well as for further research in the psychology of mastering. 
Keywords: moral consciousness; psychological readiness; moral psychological state; theory of moral foundations; emergency.

Постановка проблеми. Сучасний розвиток українського суспільства пов'язаний 3 побудовою гуманного i демократичного суспільства. Цьому процесові сприяють державні програми морального розвитку і наукові дослідження цієї проблематики. Проте особливості моральної свідомості як регулятора поведінки в умовах надзвичайних ситуацій (НС) є наразі малодослідженими.

Моральна свідомість особистості в умовах НС тісно пов'язана з іiі психологічною готовністю. Дослідження психологічної готовності особистості до надзвичайних ситуацій зосереджується на вивченні способів реагування на такі ситуації та подолання стресу, що виникає як наслідок переживання НС. Також значна увага приділяється вивченню ПТСР і наданню психологічної допомоги постраждалим унаслідок НС. Усі ці аспекти $є$ дуже важливими для формування психологічної готовності до НС у населення і працівників спеціалізованих служб, проте моральні орієнтири сприймання таких ситуацій та їхній вплив на обрання способів поведінки у вітчизняній психологічній науці досі належним чином не висвітлювалися. Це й визначає актуальність нашого дослідження.

Аналіз останніх досліджень і публікацій. Дослідження моральної свідомості наразі досить широко представлені в зарубіжній та українській психології. У зарубіжній психології концепції формування моральної свідомості та іiі особливості висвітлюються в роботах Л. Кольберга (1977), О. Веселової (2015), А. Хвостова (2001) та ін. Серед вітчизняних науковців моральну свідомість та окремі ії компоненти досліджували I. Бех (2008), I. Булах (2019), Р. Павелків (2018) та ін. Проблематика психологічної готовності до НС досить широко представлена в науковій літературі. Дослідники зосереджують свою увагу на вивченні загальних особливостей психологічної готовності до дій у НС (Духневич, 2021; Фурманець, 2006) та питаннях формування психологічної готовності у працівників ДСНС і військовослужбовців (Поканевич, 2020; Приходько, 2019). Хоча проблема моральної свідомості в умовах НС не привертала поки що особливої уваги українських дослідників, є низка робіт, що висвітлюють важливість вивчення морально-психологічного стану особистості в кризових ситуаціях і під час підготовки особового складу працівників спеціалізованих служб (Алещенко, 2018; Мась, 2017; Приходько, 2018).

У роботах зарубіжних дослідників сьогодні активно висвітлюється роль моральної свідомості в умовах НС, зокрема розглядається вплив пандемії COVID-19 на загальний психологічний стан населення (Delgado, 
2021; Rushton, 2021). Ще одним аспектом, що підтверджує важливість моральної свідомості в оцінюванні власної поведінки під час $\mathrm{HC}$, $\mathrm{\epsilon}$ напрацювання науковців у межах теорії моральних основ (Graham, \& Haidt, 2013).

Метою статті $\epsilon$ теоретичний огляд наукового доробку та висвітлення на цій основі особливостей моральної свідомості в умовах надзвичайних ситуацій та її впливу на загальний морально-психологічний стан особистості.

Виклад основного матеріалу дослідження. У психологічній літературі досі немає однозначного трактування поняття «моральна свідомість». Деякі дослідники наголошують на тому, що моральна свідомість - це культурологічний і психологічний феномен людського буття, інші ж визначають моральну свідомість як процес відображення морального аспекту суспільних подій (Бондаревська, 2011, Павелків, 2018). Незалежно від тлумачення цього феномену беззаперечним залишається той факт, що моральна свідомість $є$ регулятором поведінки особистості і формується на основі засвоєних нею моральних норм та правил. Відмітною особливістю моральної свідомості визнається здатність особистості здійснювати вільний і відповідальний вибір власних вчинків, піддавати їх аналізу та оцінці з позицій «добре - погано» i «правильно - неправильно». Моральна свідомість як регулятор поведінки активно впливає на сприйняття та осмислення особистістю надзвичайних ситуацій. Саме рівень моральної свідомості є підгрунтям формування морально-психологічного стану населення та готовності до дій в умовах НС. Цілком обгрунтованим $€$ інтерес дослідників до згаданих вище феноменів у контексті професійної підготовки працівників спеціалізованих служб. Однак надзвичайні ситуації впливають на всі верстви населення незалежно від віку, статі та професійної підготовки, що також важливо враховувати, коли йдеться про формування готовності громадян до дій у НС.

Щоб визначити місце та роль моральної свідомості в умовах надзвичайних ситуацій, доцільно спочатку розкрити зміст моральнопсихологічного стану і психологічної готовності, які 3 нею тісно пов'язані.

Складність трактування морально-психологічного стану (МПС) пояснюється тим, що його визначення в наукових джерелах i нормативних документах дається лише в контексті вивчення цього явища військовослужбовцями. Проте, на нашу думку, доцільно розширити розуміння цього поняття, адже морально-психологічний стан громадян $\epsilon$ не менш важливим фактором формування готовності до дій в умовах НС. У цьому контексті досить влучним видається визначення МПС, яке 
представив О. Іллюк. Під МПС він пропонує розуміти сукупність душевних переживань, які генеруються на чуттєвому рівні психіки людини в процесі взаємодії з об’єктивною дійсністю та усвідомлення особистісних якостей і які через систему психологічного захисту активно впливають на психічне здоров'я та проявляються в моральній діяльності (Іллюк, 2010, с. 83). У структурі МПС виокремлюють три компоненти: морально-етичний, професійний та психологічний. Найбільшою мірою моральна свідомість впливає на морально-етичний компонент, адже він проявляється через світогляд особистості, своєрідність реагування на моральні й етичні аспекти подій та обставин відповідно до сформованих моральних переконань і цінностей.

Моральна свідомість впливає і на психологічну готовність до НС. Проблема психологічної готовності до НС $\epsilon$ актуальним напрямом наукових досліджень, що пояснюється тим, що сучасне суспільство, незважаючи на шалені темпи технологічного розвитку, є дуже вразливим перед «обличчям» катастроф i часто буває не готовим до них. Проблематика психологічної готовності знайшла своє відображення в теоретичному i практичному доробку науковціву щодо професійної підготовки в особливих, напружених умовах (Поканевич, 2020, Фурманець, 2007). Загалом, психологічну готовність до НС можна трактувати як сукупність особистісних якостей, які забезпечують адекватне реагування на різні ситуативні зміни, враховуючи набутий раніше досвід, опановуючи при цьому особисті емоційні реакції та бажання (Бондаренко, \& Сергієнко, 2014; Духневич, 2021). Взаємозв’ язок психологічної готовності і моральної свідомості яскраво відбивається в процесі оцінювання НС. Процес обрання стратегії поведінки в момент НС обмежений у часі, тому дюдина має швидко оцінити ситуацію та зробити вибір на користь певних дій 3 огляду на власну систему ціннісних орієнтацій, моральних переконань та соціальних норм. Часто перешкодою у прийнятті рішення стає необхідність порушити моральні норми та правила, що супроводжується страхом смерті, звинувачень 3 боку оточення, отримання різного роду травм.

Взаємозв'язок моральної свідомості 3 МПС і психологічною готовністю до НС дає підстави стверджувати, що іiі роль в умовах НС потребує більш глибокого вивчення, адже процес опанування таких ситуацій не відбувається без залучення моральної сфери особистості. Залучення моральної свідомості під час НС відбувається не одразу, що пояснюється раптовістю настання ситуації та сильним емоційним потрясінням. Нехтування моральним підгрунтям у своїх діях на початку НС часто дає людині змогу зберегти власне життя, адже після мобілізації 
всіх особистісних ресурсів їі поведінка починає оцінюватися в категоріях «добре-погано» і «правильно-неправильно».

Роль моральної свідомості як регулятора поведінки в умовах НС можна розкрити за допомогою теорії моральних основ (ТМО), яку запропонували у 2004 році психологи Дж. Хайдт і Дж. Грехем. ТМО є відносно новим напрямом дослідження моральної сфери особистості, оскільки розкриває природу моралі не на основі умовних визначень, які було запозичено з філософії, а на основі дослідження та аналізу фактів, пов'язаних 3 моральною регуляцією поведінки особистості. Мораль у межах ТМО розглядається як система способів і критеріїв оцінки дій особистості як правильних або неправильних (Graham, 2011). Одним із вихідних положень ТМО стала соціально-інтуїтивна модель моралі, відповідно до якої моральні рішення (первинні) приймаються здебільшого на основі автоматичної, інтуїтивної, емоційної оцінки (moral intuition), а подальші (вторинні) моральні судження слугують для раціонального пояснення вже прийнятого рішення (Haidt, \& Bjorklund, 2008). За такої умови вторинні моральні судження виконують соціальну функцію, пов'язану з потребою пояснити іншим людям зроблені оцінки та прийняті рішення. Поняття «моральні основи» (moral foundations) використовується для позначення загальних, базових механізмів та критеріїв (основ) моральної оцінки різних подій та вчинків. Набір таких моральних основ розширює можливості для характеристики моральної сфери особистості. На основі теоретичного аналізу та узагальнення емпіричних даних авторами ТМО виокремлено шість моральних основ (Graham, \& Haidt, 2013):

1) турбота (Harm) - схвалення турботи про близьких, про слабких і беззахисних, заборона на заподіяння емоційної та фізичної шкоди;

2) справедливість (Fairness) - справедливе, неупереджене ставлення, рівність, честь;

3) група (Ingroup) - відданість інтересам групи, нетерпимість до зради;

4) авторитет (Authority) - дотримання традицій, загальних правил, повага до влади, дотримання ієрархії;

5) чистота (Purity) - засудження огидних, ганебних учинків, розбещеності, схвалення чистоти думок і шанування святинь;

6) свобода (Freedom) - прагення відстоювати власну позицію та власні погляди.

Перші дві моральні основи (турбота і справедливість) зосереджені переважно навколо індивідуальних відносин людей, тому їх об'єднують в індивідуалізовані моральниі основи, або «етику автономії» (ethics of autonomy). Інші моральні основи загалом стосуються відносин між 
людиною й оточенням та спонукають до згуртованості навколо лідера, загальних цінностей та святинь, тому їх називають моральними основами згуртовування, або «етикою співтовариства» (ethics of community) (Graham, \& Haidt, 2013).

Відповідно до ТМО особливості моральної свідомості в умовах НС будуть проявлятися в оцінці можливих стратегій поведінки з позицій «правильно-неправильно», а також у пошуку аргументів на користь прийнятого рішення задля пояснення його оточенню. Як зазначалося вище, у момент настання НС поведінка людини не має морального підгрунтя, але попередня оцінка ситуації відбувається 3 урахуванням моральних основ. Людина більш тривало та інтенсивно реагує на соціальні (антропогенні) НС, де наявний людських фактор, ніж на природні катастрофи. Наслідки природних НС украй рідко супроводжуються почуттям провини, але у випадку антропогенних НС зазвичай мають місце прояви почуття провини, люті і т. ін. Зазначені особливості пояснюються особливостями сприйняття самої $\mathrm{HC}$ з урахуванням моральних основ та особистих емоцій. Після залучення моральної свідомості моральну оцінку отримує не тільки ситуація, а й поведінка людини.

Розгляньмо спочатку оцінку можливих стратегій поведінки 3 позицій «етики автономії». Людина починає обирати між категоріями «турботи-шкоди» і «справедливості-обману». У категорії «турботашкода» постає вибір між діями задля збереження власного життя і діями, які можуть спричинити фізичні ушкодження, але врятують інших людей. Категорія «справедливості-обману» передбачає вибір між діями, які дають змогу зберегти власну гідність та честь, і діями, які потребують додатково виправдання перед оточенням. У момент вибору на користь одного з векторів поведінки людина потрапляє в ситуацію морального конфлікту. Оцінка всіх можливих наслідків власного вибору обмежена в часі, тому що реагувати потрібно миттєво, що значно погіршує емоційний стан людини. На іiі дії також впливають особистісні якості, такі як толерантність, альтруїм, екзистенційна відповідальність. Людина намагається вчинити «правильно», щоб не відчувати мук совісті в подальшому. У деяких випадках під час НС вона керується виключно моральними основами категорії «етики автономії», що пояснюється пріоритетними інтуїтивними відчуттями, як потрібно вчинити. У контексті формування психологічної готовності важливу роль відіграють також моральні основи категорії «етики співтовариства». Ця категорія відображає сформованість системи моральних переконань, соціальну зрілість та просоціальність особистості. Керуючись моральними основами категорії «етики співтовариства», дюдина прагне вчиняти правильно 3 позиції соціальних настановлень та соціальної бажаності. 
Регуляція поведінки в такому випадку спрямована на уникнення осуду 3 боку суспільства та відповідності всім моральним і культурним нормам. Співвідношення всіх зазначених вище моральних основ i визначає особливості поведінки під час НС.

Варто зазначити, що моральні основи, виокремлені в межах ТМО, охоплюють увесь спектр загальноприйнятих моральних норм та правил, хоч автори теорії не виключають можливості виокремлення нових основ у подальшому. Проте подальшого уточнення потребує питання відображення цих моральних основ у моральній свідомості особистості. Проаналізувавши науковий доробок, де розглядається теорія моральних основ, ми виокремили компоненти моральної свідомості, які дають змогу відобразити розуміння, засвоєння людиною зазначених моральних основ та іiі ставлення до них. Моральна свідомість у нашому дослідженні представлена чотирма компонентами: регулятивним, особистісним, соціальним і ставленнєвим. Зазначені компоненти перебувають у тісній взаємодії і дають змогу, враховуючи засвоєні моральні основи та життєвий досвід, виокремлювати можливі стратегії поведінки з подальшою їх оцінкою. В умовах НС інколи доводиться виходити за межі загальноприйнятих моральних норм. Такий «вихід» вимагає від людини чіткого усвідомлення власних можливостей та обов'язків. Це стає першочерговим завданням під час підготовки працівників спеціалізованих служб та надання допомоги постраждалим. У процесі формування готовності до НС особа має навчитися виходити за межі моральних основ, які унеможливлюють виконання своїх обов'язків. Оцінку НС i вибір стратегії поведінки за участю моральної свідомості представлено на рисунку.

Представлена модель дає змогу розкрити особливості моральної поведінки людини в умовах НС. 3 огляду на результати теоретичного аналізу і представлену модель впливу моральної свідомості на оцінку НС та вибір стратегій поведінки не залишається сумнівів, що моральна свідомість потребує подальшого вивчення в контексті НС, адже це дасть змогу застосовувати отримані результати в процесі формування психологічної готовності до НС.

Висновки. Отже, готовність громадян до надзвичайних ситуацій та їхній морально-психологічний стан $є$ важливим запитом сучасного суспільства, адже сьогодення вщерть наповнене надзвичайними ситуаціями. Предметом нашої уваги стала моральна свідомість та іï прояв в умовах НС. Неможливість уникнути моральної оцінки ситуації та поведінки в умовах НС дає підстави стверджувати, що врахування особливостей моральної свідомості в умовах НС є важливою умовою для удосконалення процесу формування психологічної готовності особис- 
тості та покращення іï морально-психологічного стану в умовах НС. 3 огляду на те, що кожна людина по-різному розуміє моральні основи та формує індивідуальне ставлення до них, виникає потреба в більш детальному вивченні цих особливостей. Теоретичний аналіз наукових джерел дав змогу виокремити та представити новий напрям у дослідженні моральної сфери особистості. Теорія моральних основ широко використовується в зарубіжних наукових дослідженнях. Для української науки це новий напрям, що становить значний дослідницький інтерес.

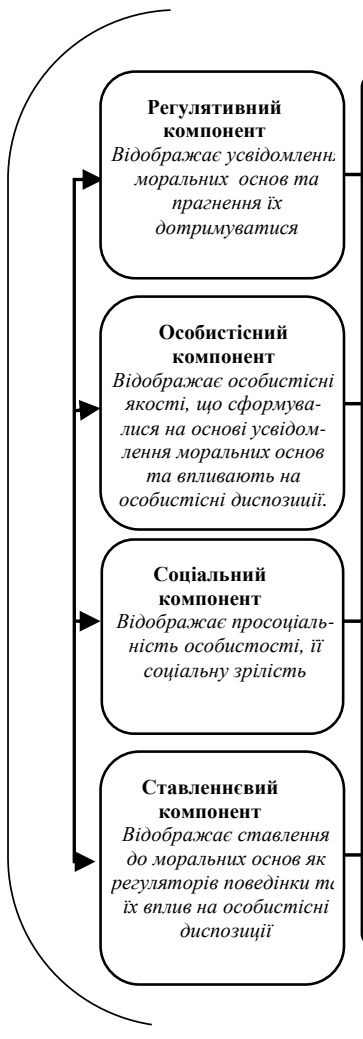

Надзвичайна ситуація
Надзвичайна ситуація

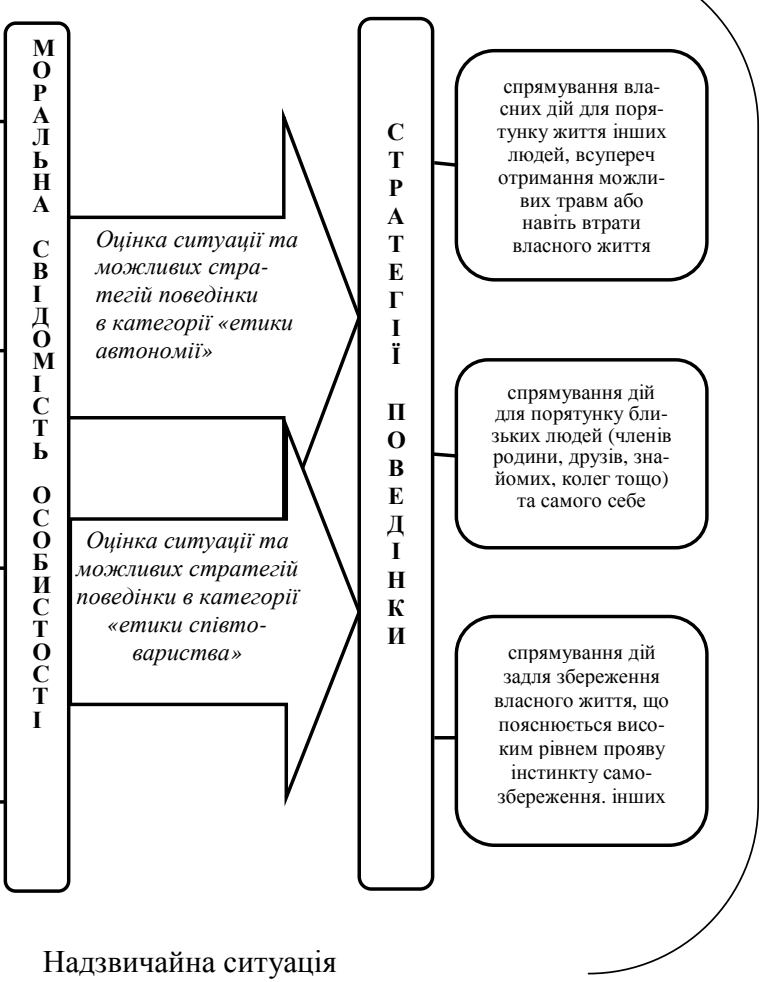

Рuc. Модель впливу моральної свідомості на оцінку НС і вибір стратегій поведінки 
Перспективи подальших розвідок убачаємо в більш глибокому аналізі теорії моральних основ та емпіричному дослідженні моральної свідомості в межах цього підходу. Виокремлення типів моральної свідомості та подальша їх специфікація поглиблять також розуміння моральної свідомості.

\section{Список використаних джерел}

Алещенко, В. І. (2018). Методичні підходи до аналізу, оцінювання та прогнозування морально-психологічного стану особового складу. Вісник Київського начіонального університету імені Т. Шевченка. Серія: Військовоспецііальні науки, 3(40), 6-10. Взято 3 http://nbuv.gov.ua/UJRN/VKNU_ vsn_2018_3_3

Бех, І. Д, (2008). Виховання особистості: у 2-х. кн. Кн. 1. Особистісно орієнтований підхід: теоретико-технологічні засади. Київ: Либідь.

Бондаревская, Е. В. (2001). Смыслы и стратегии личностноориентированного воспитания. Педагогика, 1, 17-24.

Булах, І. С. (2019). Психологічні механізми особистісного зростання підлітків. Проблеми сучасної психології, 8, 104-114

Веселова, Е. К. (2015). Практические занятия в рамках программ духовнонравственного воспитания в вузе. Методические материалы. Образовательные технологии, 1, 89-117.

Духневич, В. М. (2021). Готовність громади до викликів надзвичайної ситуації: психологічний ракурс. Наукові студї із сочіальної та політичної психологіï, 47 (50), 151-159. DOI: 10.33120/ssj.vi47(50).219

Іллюк, О. О. (2010). Методика оцінювання та прогнозування психологічних втрат i психологічної безпеки військовослужбовців на основі їх морального духу та морально-психологічного стану. Честь $i$ закон, 4, 82-93. DOI: $10.33405 / 2078-7480 / 2010 / 0 / 4 / 145002$

Мась, Н. М. (2017). Методика оцінки морально-психологічного стану особового складу ЗСУ в особливий період. Вісник Київського національного університету імені Т. Шевченка. Серія: Військово-спеціальні науки, 2 (37), 31-34.

Павелків, Р. В. (2018). Рефлексія як психологічний механізм моральної саморегуляції поведінки особистості. Психологія: реальність і перспективи, 11, $5-10$.

Поканевич, О., (2020). Формування психологічної готовності до професійної діяльності у майбутніх пожежників-рятувальників. Збірник наукових праць Національної академії Державної прикордонної служби України. Серія: психологічні науки, 12(1), 250-265.

Приходько, I. I., \& Лиман, А. А. (2019). Сприйняття ситуацій ризику військовослужбовцями Національної гвардії України та психологічна готовність до них. Честь $і$ Закон, 3(70), 105-113. DOI: 10.33405/2078-7480/2019/3/70/190044 
Приходько, І. І., Волошко, С. А., \& Гунбін, К. Ю. (2018). Теоретичні аспекти оцінювання морально-психологічного стану військовослужбовців Національної гвардії України. Честь $і$ закон, (2), 89-96. DOI: 10.33405/2078$7480 / 2018 / 2 / 65 / 139232$

Сергієнко, Ю., Бондаренко, В., \& Решко, С. (2014). Педагогічні особливості навчання майбутніх правоохоронців ефективної діяльності в умовах зіткнення 3 озброєним супротивником. Молодіжний науковий вісник Східноєвропейського національного університету імені Лесі Українки. Фізичне виховання і спорт, (16), 70-74.

Тверезовська, Н. Т. Вплив надзвичайних ситуацій на психологічний стан людини. Гуманітарні студї: педагогіка, психологія, філософія, 3(11 (3)), 75-83. doi: 10.31548/hspedagog2020.03.075

Фурманець, Б. І. (2007). Психологічна готовність до дій в надзвичайних ситуаціях. Взято 3 http://nuczu.edu.ua/sciencearchive/ProblemsOfExtreme AndCrisisPsychology/vol1/31.pdf.

Хвостов, А., \& Иванова, А. (2001). Моральное сознание молодежи России (на материале исследования молодежи Москвы и Кубани). Развитие личности, 2, $78-111$.

Delgado, J., Siow, S., de Groot, J., McLane, B., \& Hedlin, M. (2021). Towards collective moral resilience: the potential of communities of practice during the COVID19 pandemic and beyond. Journal of Medical Ethics, 47(6), 374-382. doi: 10.1136/medethics-2020-106764

Graham, J., Haidt, J., Koleva, S., Motyl, M., Iyer, R., \& Wojcik, S. (2013). Moral foundations theory: The pragmatic validity of moral pluralism. Advances in experimental social psychology, 47, 55-130. doi: 10.1016/B978-0- 12-407236-7.00002-4

Graham, J., Nosek, B.A., Haidt, J., Iyer, R., \& Koleva, S. (2011). Mapping the moral domain. Journal of personality and social psychology, 101(2). 366-385. doi: $10.1037 / \mathrm{a} 0021847$

Haidt, J., \& Bjorklund, F. (2008). Social intuitionists answer six questions about morality. Retrieved from https://papers.ssrn.com/sol3/papers.cfm?abstract_id=855164

Kohlberg, L., \& Hersh, R. H. (1977). Moral development: A review of the theory. Theory into practice, 16(2), 53-59. doi: 10.1080/00405847709542675

Rushton, C. H., Thomas, T. A., Antonsdottir, I. M., Nelson, K. E., Boyce, D., Vioral, A., ... \& Hanson, G. C. (2021). Moral Injury and Moral Resilience in Health Care Workers during COVID-19 Pandemic. Journal of Palliative Medicine. doi: 10.1089/jpm.2021.0076

\section{References}

Aleshchenko, V. I. (2018). Metodychni pidkhody do analizu, otsiniuvannia ta prohnozuvannia moralno-psykholohichnoho stanu osobovoho skladu [Methodical approaches to the analysis, assessment and forecasting of the moral and psychological state of the personnel]. Visnyk Kyivskoho natsionalnoho universytetu imeni 
T. Shevchenka. Seriia: Viiskovo-spetsialni nauky [Bulletin of Taras Shevchenko National University of Kyiv. Series: Military Special Sciences], 3(40), 6-10. Retrieved from http://nbuv.gov.ua/UJRN/VKNU_vsn_2018_3_3 (in Ukrainian)

Bekh, I. D. (2008) Vykhovannia osobystosti: $U 2 \mathrm{kn}$. Kn. 1: Osobystisnooriientovnyi pidkhid: teoretyko-tekhnolohichni zasady [Education of personality in 2 books. Book 1 Personality-oriented approach: theoretical and technological principles]. Kyiv: Lybid. (in Ukrainian)

Bondarevskaia, E. V. (2001). Smysly i strategii lichnostno-orientirovannogo vospitaniia [Meanings and strategies of personality-oriented education.]. Pedagogika [Pedagogy], 1, 17-24. (in Russian)

Bulakh, I. S. (2019) Psyholohichni mehanizmy osobystisnoho zrostannia pidlitkiv [Psychological mechanisms of personal growth of adolescents]. Problemy suchasnoi pskyholohii [Problems of modern psychology], 8, 104-114. (in Ukrainian)

Delgado, J., Siow, S., de Groot, J., McLane, B., \& Hedlin, M. (2021). Towards collective moral resilience: the potential of communities of practice during the COVID19 pandemic and beyond. Journal of Medical Ethics,47(6), 374-382. doi: 10.1136/medethics-2020-106764 (in English)

Dukhnevych V. M. (2021). Hotovnist hromady do vyklykiv nadzvychainoi sytuatsii: psykholohichnyi rakurs [Community readiness for the challenges of an emergency: a psychological perspective]. Scientific Studios on Social and Political Psychology,(47 (50), 151-159. doi: 10.33120/ssj.vi47(50).219 (in Ukrainian)

Furmanets, B. I. (2007). Psykholohichna hotovnist do dii v nadzvychainykh sytuatsiiakh [Psychological readiness to act in emergencies]. Retrieved from http://nuczu.edu.ua/sciencearchive/ProblemsOfExtremeAndCrisisPsychology/vol1/31.p df (in Ukrainian)

Graham, J., Haidt, J., Koleva, S., Motyl, M., Iyer, R., \& Wojcik, S. (2013). Moral foundations theory: The pragmatic validity of moral pluralism. Advances in experimental social psychology, 47, 55-130. doi: 10.1016/B978-0- 12-407236-7.000024 (in English)

Graham, J., Nosek, B.A., Haidt, J., Iyer, R., \& Koleva, S. (2011). Mapping the moral domain. Journal of personality and social psychology, 101(2), 366-385. doi: 10.1037/a0021847 (in English)

Haidt, J., \& Bjorklund, F. (2008). Social intuitionists answer six questions about morality. Retrieved from https://papers.ssrn.com/sol3/papers.cfm?abstract_id=855164 (in English)

Illiuk, O. O. (2010). Metodyka otsiniuvannia ta prohnozuvannia psykholohichnykh vtrat i psykholohichnoi bezpeky viiskovosluzhbovtsiv na osnovi yikh moralnoho dukhu ta moralno-psykholohichnoho stanu [Community readiness for the challenges of an emergency: a psychological perspective]. Chest $i$ zakon [Honor and Law], 4, 82-93. doi: 10.33405/2078-7480/2010/0/4/145002 (in Ukrainian)

Khvostov, A., Ivanova, A. (2001). Moralnoye soznaniye molodezhi Rossii (na materiale issledovaniya molodezhi Moskvy i Kubani) [Moral consciousness of the 
youth of Russia (based on the study of youth in Moscow and Kuban)]. Razvitiye lichnosti [Personal development], 2, 78-111. (in Russian)

Kohlberg, L., \& Hersh, R. H. (1977). Moral development: A review of the theory. Theory into practice, 16(2), 53-59. doi: 10.1080/00405847709542675 (in English)

Mas, N. M. (2017). Metodyka otsinky moralno-psykholohichnoho stanu osobovoho skladu ZSU v osoblyvyi period [Methods of assessing the moral and psychological condition of the personnel of the Armed Forces in a special period]. Visnyk Kyivskoho natsionalnoho universytetu imeni T. Shevchenka. Seriia: Viiskovospetsialni nauky [Bulletin of Taras Shevchenko National University of Kyiv. Series: Military Special Sciences], 2 (37), 31-34. (in Ukrainian)

Pavelkiv, R. V. (2018) Refleksiia yak psykholohichnyi mekhanizm moralnoi samorehuliatsii povedinky osobystosti [Reflexion as a psychological mechanism of moral self-regulation of behavior of a particular person]. Psykholohiia: realnist $i$ perspektyvy [Psychology: reality and perspectives], 11, 5-10. (in Ukrainian)

Pokanevych, O. (2020). Formuvannia psykholohichnoi hotovnosti do profesiinoi diialnosti u maibutnikh pozhezhnykiv riatuvalnykiv [Formation of psychological readiness for professional activity in future firefighters and rescuers]. Zbirnyk naukovykh prats Natsionalnoi akademii Derzhavnoi prykordonnoi sluzhby Ukrainy. Seriia: psykholohichni nauky [Collection of scientific works of the National Academy of the State Border Guard Service of Ukraine. Series: Psychological Sciences], 12(1), 250-265. (in Ukrainian)

Prykhodko, I. I., \& Lyman, A. A. (2019). Spryiniattia sytuatsii ryzyku viiskovosluzhbovtsiamy Natsionalnoi hvardii Ukrainy ta psykholohichna hotovnist do nykh [Perception of risk situations by servicemen of the National Guard of Ukraine and psychological readiness for them]. Chest i Zakon [Honor and Law], 3(70), 105-113. doi:10.33405/2078-7480/2019/3/70/190044 (in Ukrainian)

Prykhodko, I. I., Voloshko, S. A., \& Hunbin, K. Yu. (2018). Teoretychni aspekty otsiniuvannia moralno-psykholohichnoho stanu viiskovosluzhbovtsiv Natsionalnoi hvardii Ukrainy [Theoretical aspects of assessing the moral and psychological condition of servicemen of the National Guard of Ukraine]. Chest $i$ zakon [Honor and Law], (2), 89-96. doi: 10.33405/2078-7480/2018/2/65/139232 (in Ukrainian)

Rushton, C. H., Thomas, T. A., Antonsdottir, I. M., Nelson, K. E., Boyce, D., Vioral, A., ... \& Hanson, G. C. (2021). Moral Injury and Moral Resilience in Health Care Workers during COVID-19 Pandemic. Journal of Palliative Medicine. doi: 10.1089/jpm.2021.0076 (in English)

Serhiienko, Yu., Bondarenko, V., \& Reshko, S. (2014). Pedahohichni osoblyvosti navchannia maibutnikh pravookhorontsiv efektyvnoi diialnosti $\mathrm{v}$ umovakh zitknennia $\mathrm{z}$ ozbroienym suprotyvnykom [Pedagogical features of training of future militiamen of effective activity in the conditions of collision with the armed opponent]. Molodizhnyi naukovyi visnyk Skhidnoievropeiskoho natsionalnoho universytetu imeni Lesi Ukrainky. Fizychne vykhovannia i sport [Youth Scientific Bulletin of the Lesya 
Ukrainka East European National University. Physical Education and Sports], (16), 7074. (in Ukrainian)

Tverezovska, N. T. Vplyv nadzvychainykh sytuatsii na psykholohichnyi stan liudyny[Influence of emergencies on the psychological state of man.]. Humanitarni studii: pedahohika, psykholohiia, filosofiia [Humanities: pedagogy, psychology, philosophy], 3(11 (3)), 75-83. doi: 10.31548/hspedagog2020.03.075 (in Ukrainian)

Veselova, E. K. (2015). Prakticheskiye zanyatiya v ramkakh programm dukhovno-nravstvennogo vospitaniya $\mathrm{v}$ vuze. Metodicheskiye materialy [Practical classes in the framework of programs of spiritual and moral education at the university. Methodical materials.]. Obrazovatelnyye tekhnologii [Educational technologies], 1, 89117. (in Russian) 